\title{
THE UTILIZATION OF THE TAILINGS FROM WET MAGNETIC SEPARATION AT THE KRIVOY ROG GOK ${ }^{\star}$
}

\author{
U.A. KHVATOV, Z.P. ARMASHOVA, V.M. MALY, N.K. GARDASH, \\ V.P. KOLOS, YU.A. KNYAZHITSKY, L.V. KAPTILAYA, \\ V.P. SHELUDKO \\ Mekhanobrchermet Institute, 3 Televisionnaya St., Krivoy Rog, \\ 324087 Ukraine
}

Abstract A new technique of beneficiation of tailings from the Krivoy Rog magnetite ore is described. By employing a high-intensity separator, the iron-rich and iron-poor products are obtained. These products can be used in building industry: the iron-rich fraction can be used as a correction component of a raw material in the production of the portland cement clinker, as a replacement for the pyrite cinder. The iron-poor product can be used for the manufacture of bricks and other building materials.

\section{INTRODUCTION}

The Krivoy Rog beneficiation plant generates more than 60 million cubic meters of tailings annually. From the beginning of the operation of the GOK (The Mining and Beneficiation Complex) 1.5 billion cubic meters of tailings have been accumulated [1].

In order to explore a possibility of utilisation of the tailings from the magnetite ore in the building industry in the Novokrivoy Rog Mining and Beneficiation Complex (NKGOK), production-scale investigations of beneficiation of the tailings were carried out using the high-intensity carousel electromagnetic separator EKMF -600 .

In contrast to other separators, the EKMF -600 machine uses expanded metal as a matrix [2]. High selectivity of separation is achieved by matching the size of the 
matrix elements with particle size distribution of the feed material. Independence of each zone of the separator allows to obtain, in one system, various regimes of separation. The mean magnetic induction in the working zone of the separator is 0.5 Tesla, while the maximum value is 0.9 Tesla.

Investigation were carried out using a circuit comprising the carousel separator EKMF -600 [3]. Schematic diagram of the circuit is shown in Fig. 1. The tailings fed into the circuit contained 13.8 to $16.3 \%$ of iron, and 1.2 to $3.2 \%$ of the magnetic iron. Granulometric and lithographic analyses of the tailings are shown in Tables 1 and 2.

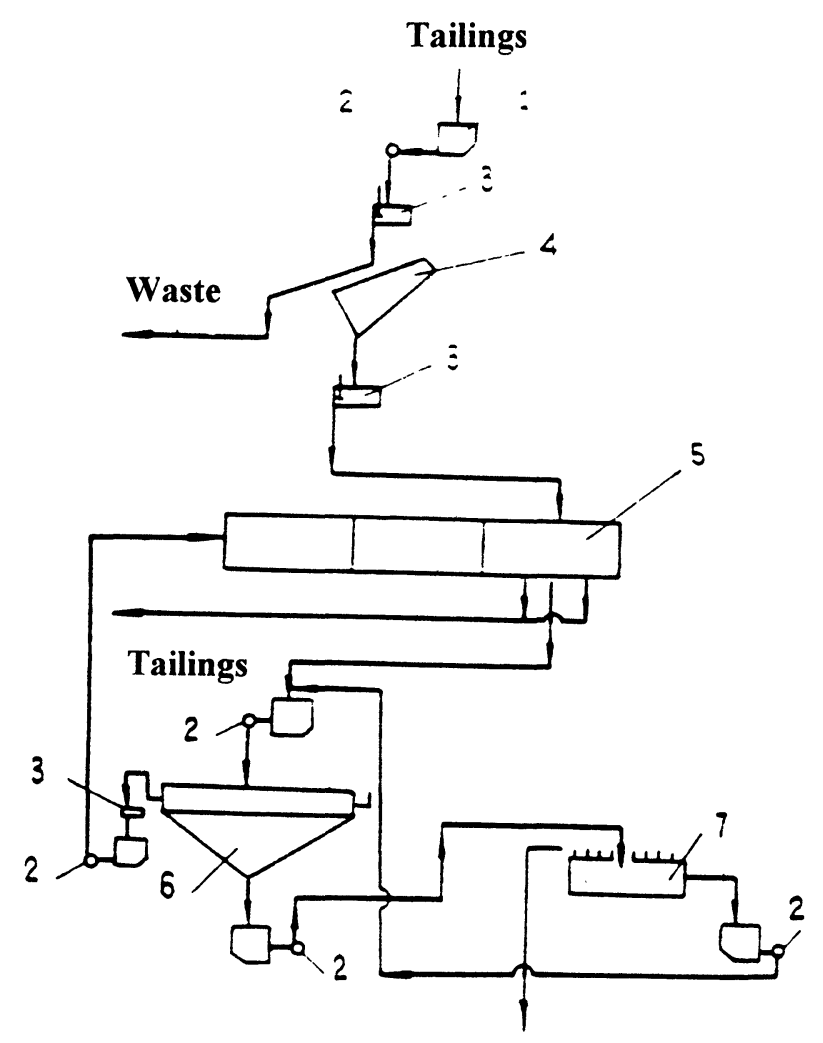

Magnetic product

Fig. 1 Schematic diagram of the circuit. 1-sump, 2-pump, 3-measuring probe, 4-inertial screen, 5-high-intensity magnetic separator, 6-thickener, 7-disc vacuum filter 
Table 1 Granulometric composition of tailings from the magnetite ore (Beneficiation plant no.2)

\begin{tabular}{|c|c|c|c|c|c|c|c|c|}
\hline \multirow{4}{*}{$\begin{array}{l}\text { Size fraction } \\
\quad(\mathrm{mm})\end{array}$} & \multicolumn{8}{|c|}{ Period of sample collection, 1990} \\
\hline & \multicolumn{4}{|c|}{ March } & \multicolumn{4}{|c|}{ May } \\
\hline & \multirow[b]{2}{*}{$\begin{array}{l}\text { Yield } \\
(\%)\end{array}$} & \multicolumn{2}{|c|}{ Mass fraction, $\%$} & \multirow{2}{*}{$\begin{array}{l}\text { Recove } \\
\text { ry, \%Fe }\end{array}$} & \multirow{2}{*}{$\begin{array}{l}\text { Yield } \\
(\%)\end{array}$} & \multicolumn{2}{|c|}{ Mass fraction, $\%$} & \multirow{2}{*}{$\begin{array}{l}\text { Recove- } \\
\text { ry, \%Fe }\end{array}$} \\
\hline & & $\mathrm{Fe}(\mathrm{tot})$ & $\begin{array}{c}\mathrm{Fe} \\
(\mathrm{mag})\end{array}$ & & & $\mathrm{Fe}$ (tot) & $\begin{array}{c}\mathrm{Fe} \\
(\mathrm{mag})\end{array}$ & \\
\hline$-0.5+0.25$ & 1.1 & 11.6 & - & 0.8 & 3.4 & 9.5 & - & 2.1 \\
\hline$-0.25+0.16$ & 2.0 & 11.4 & - & 1.4 & 4.0 & 11.2 & - & 2.9 \\
\hline$-0.16+0.1$ & 2.2 & 12.1 & - & 1.6 & 3.1 & 12.1 & - & 2.2 \\
\hline$-0.1+0.074$ & 6.5 & 13.4 & - & 5.3 & 7.6 & 12.9 & - & 5.9 \\
\hline$-0.074+0.044$ & 8.5 & 14.2 & - & 7.5 & 11.4 & 14.0 & - & 10.3 \\
\hline$-0.044+0.01$ & 50.5 & 17.3 & - & 53.6 & 46.5 & 17.4 & - & 52.1 \\
\hline$-0.01+0$ & 29.2 & 16.6 & - & 29.8 & 24.0 & 15.9 & - & 24.5 \\
\hline Total & 100.0 & 16.3 & 3.2 & 100.0 & 100.0 & 15.5 & 1.2 & 100.0 \\
\hline
\end{tabular}

Table 2 Granulometric and lithologic composition of tailings from the magnetite ores

\begin{tabular}{|c|c|c|c|c|c|c|c|}
\hline \multirow[b]{2}{*}{$\begin{array}{l}\text { Size fraction } \\
\quad(\mathrm{mm})\end{array}$} & \multirow[b]{2}{*}{$\begin{array}{l}\text { Yield } \\
(\%)\end{array}$} & \multirow[b]{2}{*}{$\begin{array}{l}\text { Mass } \\
\text { fraction } \\
\% \mathrm{Fe}\end{array}$} & \multirow[b]{2}{*}{$\begin{array}{l}\text { Recove- } \\
\text { ry, \% Fe }\end{array}$} & \multicolumn{4}{|c|}{ Lithologic composition (\%) } \\
\hline & & & & Ore & $\begin{array}{l}\text { High- } \\
\text { grade } \\
\text { concre- } \\
\text { tions }\end{array}$ & $\begin{array}{c}\text { Low- } \\
\text { grade } \\
\text { concre- } \\
\text { tions }\end{array}$ & Non-ore \\
\hline+0.5 & 0.8 & 8.0 & 0.5 & - & 2.0 & 15.0 & 83.0 \\
\hline$-0.5+0.25$ & 3.5 & 9.3 & 2.4 & - & 4.0 & 16.0 & 80.0 \\
\hline$-0.25+0.16$ & 2.6 & 9.9 & 1.9 & - & 3.0 & 20.0 & 77.0 \\
\hline$-0.16+0.1$ & 6.8 & 10.6 & 5.2 & - & 4.0 & 20.0 & 76.0 \\
\hline$-0.1+0.074$ & 5.4 & 11.9 & 4.7 & - & 2.0 & 20.0 & 73.0 \\
\hline$-0.074+0.044$ & 12.4 & 12.6 & 11.3 & 10.0 & 10.0 & - & 80.0 \\
\hline$-0.044+0.01$ & 40.9 & 15.8 & 46.8 & 5.0 & - & - & 95.0 \\
\hline 0.0 & 27.6 & 13.6 & 27.2 & 3.0 & - & - & 97.0 \\
\hline Total & 100.0 & 13.8 & 100.0 & 4.0 & 2.0 & 4.0 & 90.0 \\
\hline
\end{tabular}


During the trials, the following optimum operational parameters of the separator were established:

Throughput:

Magnetic induction

in the working zone

Speed of rotation

of the rotor
$100 \mathrm{t} / \mathrm{h}$ (with three magnetic heads)

0.25 to 0.35 Tesla

$0.8 \mathrm{rpm}$

From the tailings with the grade of $13.8 \%$ to $16.3 \% \mathrm{Fe}$, the concentrate containing $26.4 \%$ to $30.6 \% \mathrm{Fe}$ was produced, with the recovery of 30 to $35 \%$. The non-magnetic fraction contained 6.4 to $9 \% \mathrm{Fe}$, and 0.1 to $0.2 \%$ of the magnetic iron.

The magnetic concentrate was directed to the All-Union Research Institute of the Cement Industry (NIIC) with the aim to explore a possibility of using the concentrate as a raw material in the manufacture of the portland clinker, as a replacement for the pyrite cinder. Pilot-scale investigations were performed at the NIIC Institute in Podolsk.

Tables 3 and 4 show consumption of raw materials and of mixtures of raw materials per 1 tonne of clinker. It can be seen from Tables 3 and 2 that consumption of the magnetic fraction increased by a factor of 1.5, in comparison with traditional correction addition (the pyrite cinder).

Table 3 Consumption of raw materials, in $\mathrm{kg}$ per tonne of clinker

\begin{tabular}{||c|c|c|c|c|}
\hline \multirow{2}{*}{ Limestone } & \multirow{2}{*}{ Clay } & \multirow{2}{*}{ Cinder } & \multicolumn{2}{|c|}{$\begin{array}{c}\text { Iron-containing fraction } \\
\text { Mass fraction, \%Fe }\end{array}$} \\
\cline { 4 - 5 } & & & 30.60 & 26.00 \\
\hline 1389.00 & 176.00 & 22.00 & - & - \\
\hline 1393.00 & 159.00 & - & 34.00 & 38.00 \\
\hline 1396.00 & 156.00 & - & - & - \\
\hline
\end{tabular}


Table 4 Composition of mixtures of raw materials (\%)

\begin{tabular}{||c|c|c|c|c|}
\hline \multirow{2}{*}{ Limestone } & \multirow{2}{*}{ Clay } & \multirow{2}{*}{ Cinder } & \multicolumn{2}{|c|}{$\begin{array}{c}\text { Iron-containing fraction } \\
\text { Mass fraction, \%Fe }\end{array}$} \\
\cline { 4 - 5 } & & & 30.60 & 26.00 \\
\hline 81.47 & 16.31 & 2.22 & - & - \\
\hline 81.72 & 15.00 & - & 3.28 & - \\
\hline 81.36 & 14.39 & - & - & 3.75 \\
\hline
\end{tabular}

Industrial investigations thus showed a possibility of using the magnetic fraction of the tailings from magnetite ores as a correction component of the raw material in the production of the portland cement clinker.

\section{CONCLUSIONS}

The proposed technique of beneficiation of tailings of the magnetite ore using the high-intensity carousel magnetic separator EKMF-600 allows us to obtain the iron-rich and iron-poor products which can be used in the building industry.

The iron-rich product containing 26 to $38 \% \mathrm{Fe}$ can be used, without further upgrading, as a correction component of the raw material in the production of the portland cement clinker, as a replacement for the pyrite cinder.

The iron-poor product with the iron concentration of 6 to $7 \%$ can be used for the manufacture of silicate bricks, as a replacement for clay and river sand, or as a porous filler for light concrete for construction of security buildings, and for other building materials.

Introduction of tailings into the further treatment represents one of the principal directions in the increase of efficiency of the total utilisation of raw materials and the economics of mineral resources and of the environmental protection. 


\section{REFERENCES}

[1] V.S. Schebeko, A.V. Shulga and L.P. Lifanova: Gorn. Zh. No. 8 (1985), 28

[2] Yu. A. Khvatov et al.: Development of technology for beneficiation of iron ores using the high-intensity carousel magnetic separator ERMF-600. In: Maloothodniye $i$ ekologicheski chistiye tekhnologii pererabotki rud chernyh metallov. Krivoy Rog (1992), p. 103

[3] E.A. Titlyanov et al.: Gorn Zh. No. 10 (1989), 17

Keywords: magnetic separation, magnetite ore, tailings, clinker

${ }^{\star}$ This paper is an adapted version of a paper published originally in Russian in "Malootchodniye $i$ ekologicheski chistiye tekhnologii pererabotki rud chernych metallov", Mekhanobrchermet, Krivoy Rog 1992. It is published with permission of the Mekhanobrchermet Institute. 